\title{
Ulaşım Aktarma Merkezlerinde Akıllı Kent Mobilyaları
}

\author{
Arash NAJAFIDASHTAPE ${ }^{1 *}$
}

Öz

Günümüzde farklı toplu taşıma türlerinin kesiştiği ulaşım ağırlıklı kent odakları olan aktarma merkezleri kullanıcı sayısı yoğunluğunun yanısıra fiziksel, sosyal ve psikolojik açıdan da yoğun ve karmaşık yapıya sahip mekânlardır. Bu nedenle ulaşım aktarma merkezlerinde her türde kullanıcının çeşitlenen intiyaçlarına cevap verecek, algılanabilir, kolay, seri, kesintisiz ve güvenli seyahat koşullarının sağlanmasında kent mobilyalarının rolü önemlidir. Ancak kalabalık insan grupları için toplanma ve dağılma noktası niteliğini taşıyan ulaşım aktarma merkezlerinde kent mobilyalarının uygulamaları incelendiğinde; algılama, konumlandırma, bilgilendirme, yönlendirme gibi mekânsal kullanım konuları açısından yetersiz kaldığı ve bireylerin talepleri ile bütünleşik olmadığı görülmektedir. Dolayısıyla, aktarma merkezlerini kullanan yolcu yoğunluğu ve taleplerindeki artış intiyaçların cağımızın akılı kent mobilyaları ile karşılanmasını gerektirmektedir. Ulaşım aktarma merkezlerindeki akıllı kent mobilyaları kısa süreli ve anlık yolcu intiyaçlarını destekleyen sistemlere sahip olup, özellikle bir ulaşım türünden diğerine kolay erişim sağlama ve dolayısıyla seyahat sırasında aktarmaların hızı şekilde gerçekleşmesine olanak tanıyacak nitelikte olmaktadır. Bu doğrultuda çalışmanın amacı; bireyleri algılayabilen ve enerji üretebilen nitelikleri bulunan akıllı kent mobilyalarını ulaşım aktarma merkezleri örneğinde ortaya koymaktır.

Anahtar kelime: Aktarma Merkezi, Kent Mobilyası, Akıllı Kent Mobilyaları

\section{Intelligent City Furniture at Transportation Transfer Center}

\section{ABSTRACT}

Today, the transport hub or interchange that make up the transportation focal points of the different types of public transportation are the places that have intensive and complex structure in terms of physical, social and psychological aspects as well as the density of users. Thus, the role of urban furniture is ensuring the travel conditions that can be perceived, easy, serial, uninterrupted and safe to supply the different needs of every kind of users in transfer centers. However, when the applications of the urban furniture are examined in the transfer centers, which are gathering and dispersing points for crowded groups of people, it is seen that urban furniture is inadequate or not integrated with the demands and potentials of the individuals in terms of spatial usage such as perception, positioning, informing and directing. The purpose of the article is;

\footnotetext{
${ }^{1}$ Yıldız Teknik Üniversitesi, Mimarlık Fakültesi, Şehir ve Bölge Planlama Bölümü

* İlgili Yazar / Corresponding Author: e-mail: arashalon@gmail.com

Gönderim Tarihi: 25.02 .2018

Kabul Tarihi: 25.03.2018
} 
to evaluate urban furniture in terms of, technological, intelligence and renewable energy sources within the framework of transfer center.

Keywords : Transfer Center, City Furniture, Smart City Furnitures

\section{GiRiş}

İnsan ve faaliyetlerini destekleyen temel unsurlarından biri olan kent mobilyaları, kentsel alanlarda insanlar için çeşitli hizmetler ve işlevler sunmaktadırlar. Kent mobilyaları, kentin mekânsal kalitesini belirleyen önemli unsurları teşkil etmektedir. Bu doğrultuda kent mobilyaları, hem kentlerin kimlik ve imajının oluşumu ve hem kentlerdeki merkezi alan ve mekânların işlev ve estetik özelliklerini olumlu şekilde etkilemektedirler. Bu nedenle kent mobilyaları gelişen teknoloji, değişen yaşam şartları ve kullanıcı yapısındaki değişimleri takip etmelidir. Bu yaklaşım kapsamında kent mobilyaları, kentin teknoloji temelini oluşturma açısından bulundukları kentsel mekânın kullanımını kolaylaştırmalı ve kullanıcı gereksinimlerine çağdaş sistemler aracılığıyla yanıt verebilmelidir. Kent mobilyalarının önemi, kullanıcının yoğun olduğu kentsel mekânlarda daha da artmaktadır. Bu yaklaşım kapsamında, önemli kentsel mekânlardan biri, gün içinde kullanıcı sayısının yüksek olduğu ve çeşitlilik gösterdiği ulaşım aktarma merkezleridir.

Ulaşım aktarma merkezleri; karayolu, demiryolu ve denizyolu ulaşım türleri arasında entegrasyon ve organizasyon sağlayan, bir ulaşım türünden diğerine geçmeye imkân tanıyan odak noktalardır (Albayrak, 2016). Başka bir deyişle, ulaşım aktarma merkezleri hem toplu taşıma türlerinin hem de bireysel ulaşım türlerinin (yaya, bisiklet ve otomobil) mekânsal olarak bütünleştiği alanlar olarak tanımlanmaktadır (Saraçoğlu, 2012). Ayrıca aktarma merkezleri yolcuların kentiçi toplu taşıma sistemine giriş-çıkış yaptıkları, taşıt ve yaya hareketlerine yönelik organizasyonun sağlandığı, ulaşımda toplanma-dağılma alanı rolünü üstlenen düğüm noktalarıdır (San Francisco Redevelopment Agency, 2009). Kullanıcı yoğunluğu fazla olan bu tür mekânların düzenli bir şekilde insan kitlesi ile dolması ve bu kitlenin mekândan boşaltıması büyük önem taşımaktadır. Ancak kentlerin yoğunlaşması ve nüfusun artması, ulaşım aktarma merkezleri gibi yoğun yaya akımlarının gerçekleştiği kentsel mekânlarda kontrolü güçleştirmekte ve insan izdihamına sebep olmaktadır. Bu nedenle ulaşım aktarma merkezlerinin işler olabilmesi kullanıcı akımlarının teknoloji ve akıllı sistemler sayesinde daha rahat, seri kontrol edilebilmesi ve yönlendirilmesi ile mümkün olabilmektedir. Dolayısıyla, ulaşım aktarma merkezlerinde yer alacak mobilyaların kullanım türleri ve işlevsellikleri önem kazanmaktadır.

Gelişen teknoloji sayesinde ulaşım aktarma merkezlerinde bulunan kent mobilyaları; bilgilendirme, etkileşim ve rekreasyon amaçlı işlevlerle akıllı sistemlerle tasarlanıp uygulanabilmektedir. Çalışma sonucunda, modern şehir yaşam algısı çerçevesinde ulaşım aktarma merkezlerinde bulunan mobilyaların barındırdığı özgün ve akıllı niteliği; kullanıcıların hangi intiyaçları ve davranışları doğrultusunda gelişim gösterip, bu intiyaçların ne tür bilgiler içerdiği ve bu bilgilerin nasıl bir donanıma sahip olduğu açıklanacaktır. Çalışmada ilk olarak kent mobilyalarının tanımı ve sınıflandırması 
konularına yer verilmektedir. Çalışmanın devamında akıllı kent mobilyaları tanımlandıktan sonra, bu mobilyaların akıllılık ilkesi; bireyleri algılayabilen ve enerji üretebilen mobilyalar olmak üzere iki başlık altında irdelenecektir.

\section{KENT MOBILYALARI}

Kent mobilyaları; cadde, sokak, yol, otopark, durak ve istasyonlar, seyir terasları, yeşil alanlar, yaya yolları ve meydanlar ile tüm kentsel mekânlarda bireylerin ihtiyaçları doğrultusunda, ulaşım, oturma, barınma, korunma, danışma, yönlenme, aydınlatma, çöp biriktirme, dinlenme, eğlenme ile birlikte yağış, rüzgar ve güneş ışınları gibi doğal dış etkilerden korunma gibi intiyaçları karşılamak üzere tasarlanmış ve yerleştirilmiş özgün ürünlerdir (Aksu, 2010) (Şekil 1). Kent mobilyaları, kentin fonksiyonel ve estetik değerleri açısından kent için büyük önem taşımak ile birlikte, kentin kalitesi ve kimliği üzerinde de etkili olmaktadır. Diğer yandan kent mobilyaları, kentsel ve kamusal açık alan çerçevesinde bireylerin sosyal, kültürel, fiziksel ve psikolojik intiyaçları doğrultusunda çeşitli işlevlere yanıt vermenin yanısıra, mekânı tanımlayan ve tamamlayan nitelikli elemanlardır (Şekil 2).

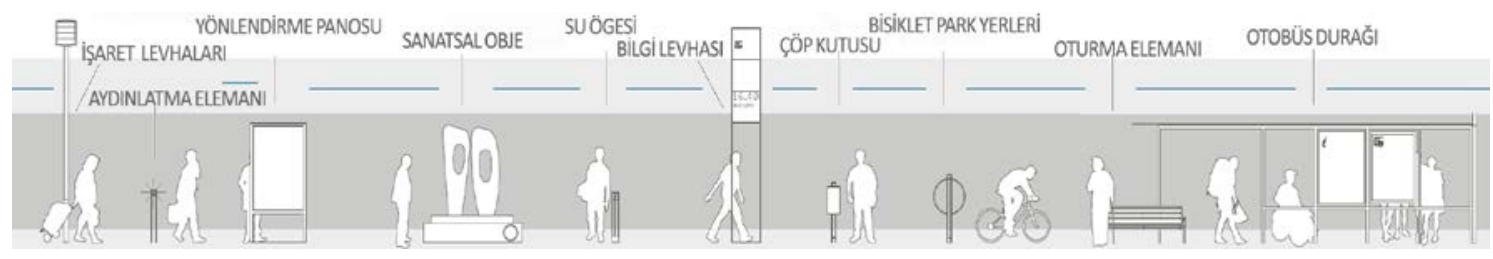

Şekil 1: Kent Mobilyaları (National Association of City Transportation Officials, 2012)

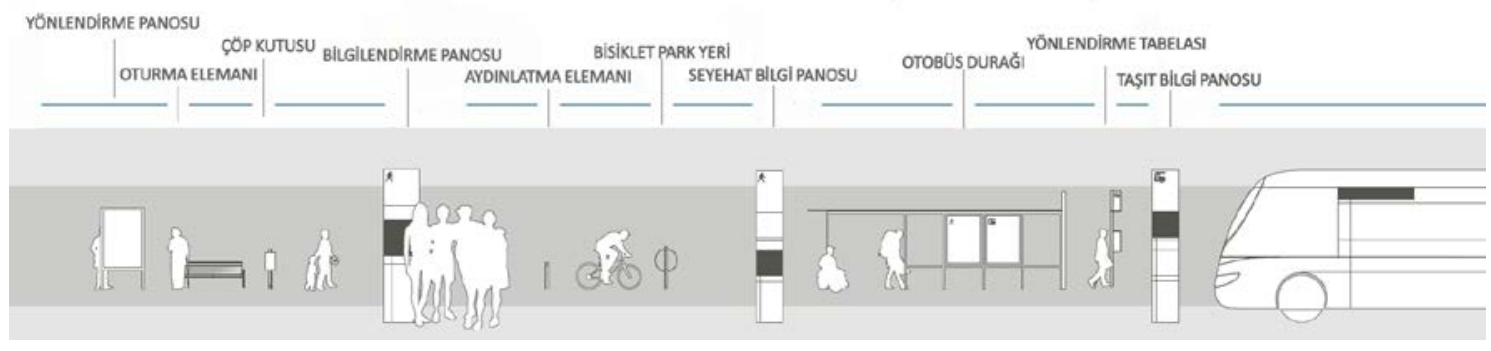

Şekil 2: Ulaşım Aktarma Merkezindeki Kent Mobilyaları (National Association of City Transportation Officials, 2012)

Kent mobilyaları kullanıldıkları mekânlara, kullanım türlerine ve işlevsel özeliklerine bağlı olarak üç başlıkta sınıflandırılmaktadır.

\section{a) Kullanım Mekânlarına Göre}

Kent mobilyalarının kullanım alanları kentsel mekânlara göre; yol kenarları ve yaya yolları, dinlenme alanları, bina kompleksleri ve çevreleri, peyzaj düzenlemelerinin olduğu yeşil alanlar, duraklar olmak üzere çeşitlenmektedir (Bayazıt, 2011, Krouwel, 2017, Sancak, 2009). 
Yol Kenarları ve Yaya Yolları: Yol kenarlarında bulunan işaret levhaları, yönlendirme panoları, bilgi levhaları, aydınlatma, taşıt ve yaya izlerini birbirinden ayıran elemanlar gibi kent mobilyaları insan ve araçların gidecekleri yönü bulmalarına yardım etmektedir. Kılavuz özelliği taşıyan bu mobilyalar, toplu taşıma güzergahları, durakları ve istasyonları, yoğun insan gruplarını taşıyan yaya yolları, özel yönlendirme noktaları, turizm bilgilenme, trafik bilgilenme, acil durum bilgilenme, gibi mekânlarda yer almaktadır.

Dinlenme Alanları: Durağan mekânlarda yer alan oturma grup ve elemanları, su ögeleri ve sanatsal objeler gibi dinlenme odaklı mobilyalar; çoğunlukla oturmak, oynamak, dinlenmek ve iletişim işlevi çerçevesinde yararlanılmaktadır. Rekreasyon alanları, bekleme alanları, tarihi çevre içindeki özel alanlar, kente kimliğini vurgulayan özel sembolik mekânlar dinlenme alanları bu gibi kent mobilyalarının kullanıldığı alanlardır.

Bina Kompleksleri ve Çevreleri: Bina kompleksleri, iş merkezleri, alışveriş merkezleri ve yeme içme mekânları, şehir merkezleri, kültür merkezleri, konut bölgeleri oturma grup ve elemanları, çöp kutusu, aydınlatma elemanları gibi kent mobilyalarının en çok kullanıldığı mekânlardır. Genellikle bu mobilyalar; bilgilendirme, iletişim, yönlendirme ve sınırlayıcı işlevleri doğrultusunda olup, yapı ve yapı grupları çevrelerinde yer almaktadırlar.

Peyzaj Düzenlemelerinin Kapsadığı Alanlar: Kentin nefes aldığı yeşil bölgeler ve kentiçi peyzaj düzenlemelerin olduğu alanlar kapsamında olan bu mobilyalar, bütün insanların dinlenme ve boş zamanları değerlendirme amacıyla kullandıkları, çocuk oyun alanları, rekreasyon alanları, açık spor alanları, gezinti alanları, dinlenme alanları, sergileme alanları ve su ögeleri gibi mekânlarda bulunmaktadırlar.

Duraklar: Duraklar insanların ulaşım amaçlı kullandıkları otobüs, tramvay, dolmuş gibi toplu taşıma araçlarının, araç trafiğinden ayrı, rahat bir bekleme amacıyla yerleştirilmiş mobilyalardır. Toplu taşıma durakları kullanıcıları rahatsız eden güneş ışınlarından ve yağmur gibi iklim koşullarından korunmasını sağlarken, toplu taşımanın sefer numarası, sıklık ve zaman bilgilerini gösteren, bilet satışı, danışma, oturarak ya da ayakta bekleme, duyuru, reklam gibi bilgilendirme amaçlı da kullanılan yarı açık-kapalı mekânları teşkil etmektedirler.

\section{b) Kullanım Türlerine Göre}

Kent mobilyalarının kullanım türleri ve bu kullanım türlerinin uygulamadaki fiziksel özellikleri dört ana grupta yer almaktadır (Moreton Bay Regional Council, 2011, Durmuş, 2008).

Geçici kullanım: Kent içinde bulunan herhangi bir mekânın, kısa süreliğine yararlanılmasına yönelik işlev taşıyan bu kullanım, genellikle ulaşım olgusu çerçevesinde olup yaya ve motorlu araçlar odaklı olmaktadır. 
Sürekli kullanım: Kent içinde bulunan herhangi bir mekânın belli bir süre, zaman harcanarak kullanılmasını kapsayan mobilyaların kullanım türüdür. Bu tür kullanım oturmak, durmak, beklemek, vakit geçirmek vb. eylemlere yönelik olup, durakları, çeşitli bekleme noktalarını, bina kompleksleri ve çevreleri ile pazar alanı gibi mekânlarda yer almaktadır.

İşlevsel kullanım: Kentiçi mekân kullanımında, gereksinimler doğrultusunda oluşturmak istenilen işlevlere ilişkin olan bu kullanım türleri, kentlinin iletişim ve fizyolojik gereksinimlerini kapsamaktadır. Bu kullanım, görsel iletişim işlevleri, sosyal bilgileri ve genel bilgilere yönelik konuları içermektedirler.

Yan Kullanımlar: yan kullanım, yukarıdaki üç tür kullanımın gerçekleşmesi sırasında oluşan etkinliklere hizmet verecek kullanımlardır. Bu kullanım düzenlenme, bakım, güvenlik hizmetleri gibi alt başlıkları olabileceği gibi çevresel estetiğe dönükte olabilmektedir. Bu tür kullanımlar, kentsel çevrenin anlam kazanmasına ve bir mekânın nitelendirilmesine olanak tanımaktadır.

\section{c) İşlevselliğe ve Verilen Hizmete Göre}

Kentsel mekânlarda bireylerin gereksinimlerini karşılamak için kullanılan mobilyaların işlevlerleri kullanım türleri ve amaçlarına göre değişim göstermektedir (Akyol, 2006, Abu Dhabi Urban Planning Council, 2013);

- Koruma ve Barındırma Amaçlı: kentiçi trafik akışını düzenleyen trafik lambaları, trafik işaret panoları, aydınlatma elemanları; gölgelikler, tenteler, otobüs durakları,

- Dinlendirme Amaçlı: oturma elemanları,

- Temiz Tutma Amaçlı: çöp kutuları,

- Eğlence Amaçlı: rekreasyon ve çocuk oyun alanlarında yer alan kent mobilyaları,

- Alış-Veriş Amaçlı: büfeler, bilet gişeleri, otomatik alış-veriş makineleri,

- İletişim Amaçlı: telefon kabinleri, şarj dolum üniteleri, internet erişimi barındıran oturma birimleri,

- Yönlendirme Amaçlı: yer döşeme kaplamaları, sokak tabelaları, alt ve üst geçit tabelaları,

- Sınırlama Amaçlı: çitler, parmaklıklar, duvarlar, çiçeklikler, ağaç dibi korumaları,

- Bilgilendirme Amaçlı: ilan ve reklam panoları, meydan saatleri, otobüs durakları,

- Süsleme Amaçlı: çiçeklikler, heykeller ve su oyunları.

\section{AKILLI KENT MOBILYALARI}

Akıllı kent mobilyaları, yenilikçi ve çevreci çözümler barındıran, insan hayatını kolaylaştıran, engelli bireyler için kolay kullanım imkânı tanıyan, teknolojik donanım sayesinde bireyler ile doğrudan iletişim kurma niteliğine sahip, yenilenebilir enerji kaynakları ile çalışabilen, yer aldıkları mekânları tanımlayan, etkileşimli kent mobilyalardır. Bu mobilyalar tasarlandıkları amaçlara göre işlevsel olmanın yanısıra bireylerin psikolojileri bakımından olumlu etkilenmeleri için estetik açısından da özgün özellikler barındırmaktadır (Doğan, 2015). Mobil ağ sistemi ile desteklenen bu 
mobilyaların kullanımında temel amaç, teknolojik bağlamda modern şehir yaşam algısı ve sosyal yaşam şartlarından kaynaklı intiyaçlara yönelik oluşan bilgi ağırlıklı gereksinimlere, çağa ayak uydurabilen sistemler ile donatılmış mekanizmalar aracılığıyla, bulundukları mekânları ön plana çıkaracak çözümler sağlamaktır.

Akıllı kent mobilyaları, teknik bakımdan güncel niteliğe sahip, barındırdığı çevre ile etkileşim özelliğinden dolayı bulundukları mekânı tanımlayan, doğrudan mesajlar verebilen, çağdaş mobilyalardır (Aksu, 2010). Ayrıca akıllı kent mobilyaları belirleyici, tanımlayıcı, bilgilendirici, yönlendirici, etkileşim olanağı yaratabilen, kültürel, politik, ekonomik ve sosyal açıdan da halkın çeşitli intiyaçlarına cevap verebilecek nitelikler içermektedir (Şekil 3).

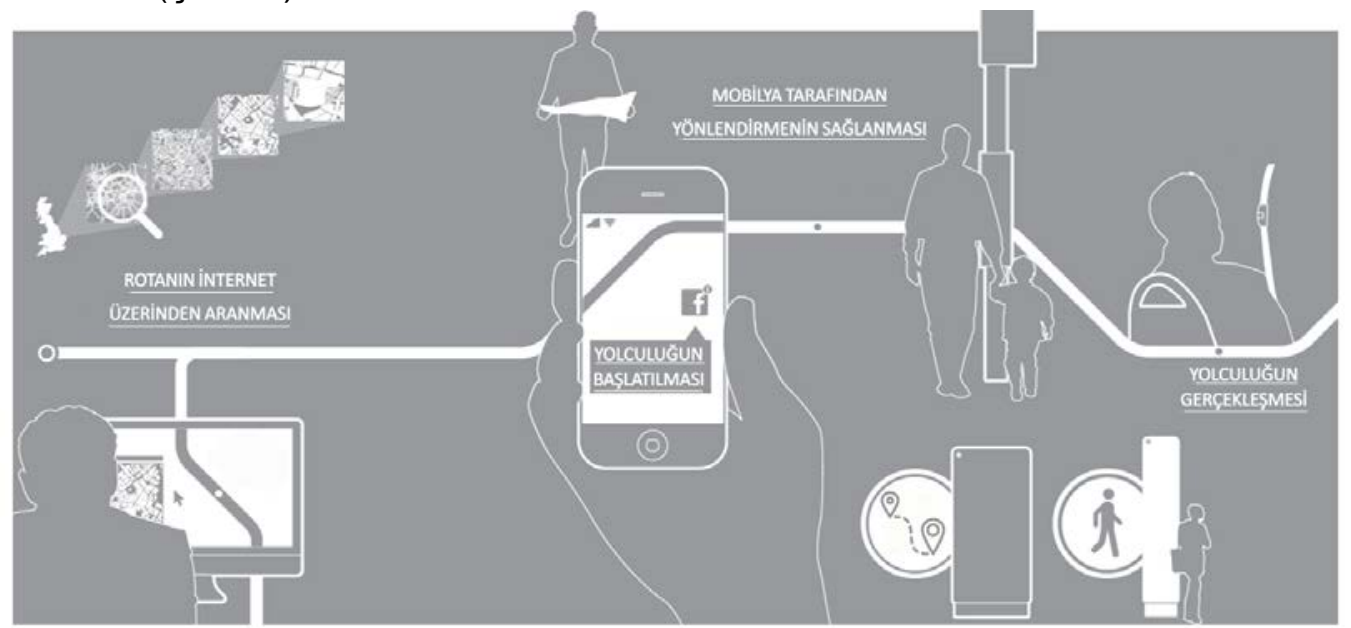

Şekil 3: Akıllı Kent Mobilyaları (Centro and City ID, 2014)

\section{ULAŞIM AKTARMA MERKEZLERINDEKI AKILLI KENT MOBILYARI}

Yolculara kesintisiz seyahat imkânı sunan ulaşım aktarma merkezleri, kentin yaşam merkezleri olup, omurgasını oluşturan asıl yollar üzerinde yer alan, yürüme mesafesindeki farklı ulaşım olanaklarının odak noktası olmaktadır. Toplu taşıt ve yaya ağırıkı kullanılan aktarma merkezleri, ulaşımın yanısıra farklı işlevleri bünyelerinde barındırmakla birlikte, kentte yaşayan bireylerin sosyal yaşamına ve alışkanlıklarına hitap eden ve zaman geçirmelerini sağlama gibi faaliyetler açısından da kentsel yaşamı destekleyen mekânlardır (Abaszadegan, Rezazade, Mohamadi, 2011, National Association of City Transportation Officials, 2012). Çalışmanın bu bölümünde ulaşım aktarma merkezlerinde bulunan akıllı kent mobilyaları; bireyleri algılayabilen ve enerji üretebilen mobilyalar olarak iki ayrı grupta ele alınmaktadır.

\section{1) Bireyleri Algılayabilen Mobilyalar}

İnsanların kent içinde haraketlilik olanakları, her gün yaşadıkları bir tecrübe olarak benimsenmektedir. Günümüzde kentlerin büyüyüp, yoğunlaşmasıyla birlikte, insanların kentiçi yolculuk yapma planları yolculuk başlamadan önce gerçekleştirilmektedir. Bu planları oluşturan temel amaç, en kısa sürede daha rahat yolculuk yapma olanağının bireyler tarafından sorgulanmasıdır. Bu nedenle birden fazla taşı ile gerçekleşen 
yolculuklarda, kullanıcılar aynı anda birçok bilgiye farklı formatta intiyaç duyabilmektedirler. Böylece günümüzün sosyal yaşam şartları ve bireylerin gereksinimleri doğrultusunda topluma sunulan bilgi ürünleri, ulaşım hizmetleri barındıran mekânlarda da teknolojik bir biçimde, erişebilir ve kullanılabilir olmaya başlamıştır (Doğan, 2015). Bu hizmetler, ulaşım aktarma merkezlerinde akıllı ve teknolojik tasarım barındıran kent mobilyaları çerçevesinde uygulamaya geçmektedir (Şekil 4). Bu çalışma kapsamında ulaşım aktarma merkezlerindeki kent mobilyaları, yolcuların istekleri doğrultusunda gereken bilgileri, internet bağlantıları ortamlarında, bireyin akıllı cihazlarına (Akıllı Telefonlar) göndererek görsel anlatımlar veya sesli mesajlar ile yönlendirme, bilgilendirme sağlamaktadırlar (Centro and City ID, 2010).

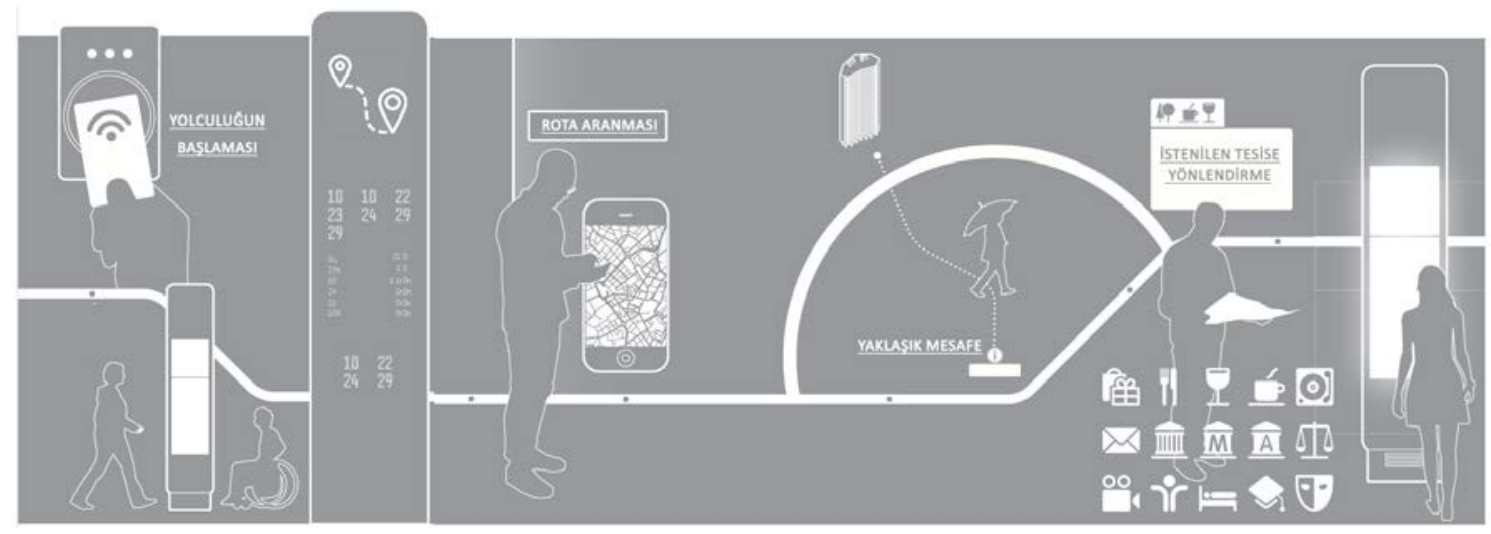

Şekil 4: Bireyleri Algılayabilen Kent Mobilyaları (Centro and City ID, 2010)

\section{Yönlendirme}

Bu tür kent mobilyaları görme engelli kişiler için yönlendirme ve diğer bireyler için de bilgilendirme amaçlı tasarlanmaktadır. Bu gibi kent mobilyaların özellikleri ve işlevi her kişiye özel bir şekilde beklentilere göre ayarlanmaktadır. Dolayısıyla engelli ve normal bireylerin yön bulması yanısıra, bir turistin kendi dilinde istediği şekilde yönlendirilmesini sağlayacak olanakları barındırmaktadır (URL-1). Kullanıcılar, sokak tabelaları şeklinde tasarlanan bu mobilyalarda, gereken kayıt işlemleri yaptıktan sonra bluetooth sinyalleri vasıtasıyla kullanıcıların telefonları arasında bağlantı kurulup, sesli mesaj veya tabelalarıdaki grafikler ile kişileri uyararak yönlendirme veya bilgilendirme sağlamaktadırlar.

\section{Bilgilendirme}

Bilgilendirme eylemi, kentte konumlanan panolardan haber, bilgi içeriği taşıyan, kısa görseller şeklinde bireyler için yayınlanmaktadır. Günümüzde bu panoların yeni nesilleri akıllı teknoloji çerçevesinde uzaktan kumanda edilebilen, daha cazip bilgiler ve değişik hizmetler sunmak için tasarlanmaktadırlar (JCDecaux, 2012) .

Ulaşım aktarma merkezlerinde otobüs, tramvay durakları veya bilgi panoları şeklindeki platformları kapsayan bu işlev, genellikle bireyler için yön bulma, toplu taşıma araçlarının seferlerine dair hareket, varış ya da uğrama saatleri, trafik yoğunluğu ile 
ilgili konular, bireylere en uygun olanak tanıyan alternatif taşıtlar, kent ile ilgili önemli veri ve bilgileri, hava durumları ve kısa yolculuk için bilinmesi gereken bilgileri içermekle birlikte kent bütününde reklam içerikli bilgilerin de yayınlanmasına olanak tanımaktadırlar (Şekil 5). Bu bağlamdaki temel konu, aktarma merkezindeki gerekli bilgilerin bütün yolculara tarafından kolayca ve sorun yaşamaksızın erişebilir olmasıdır.

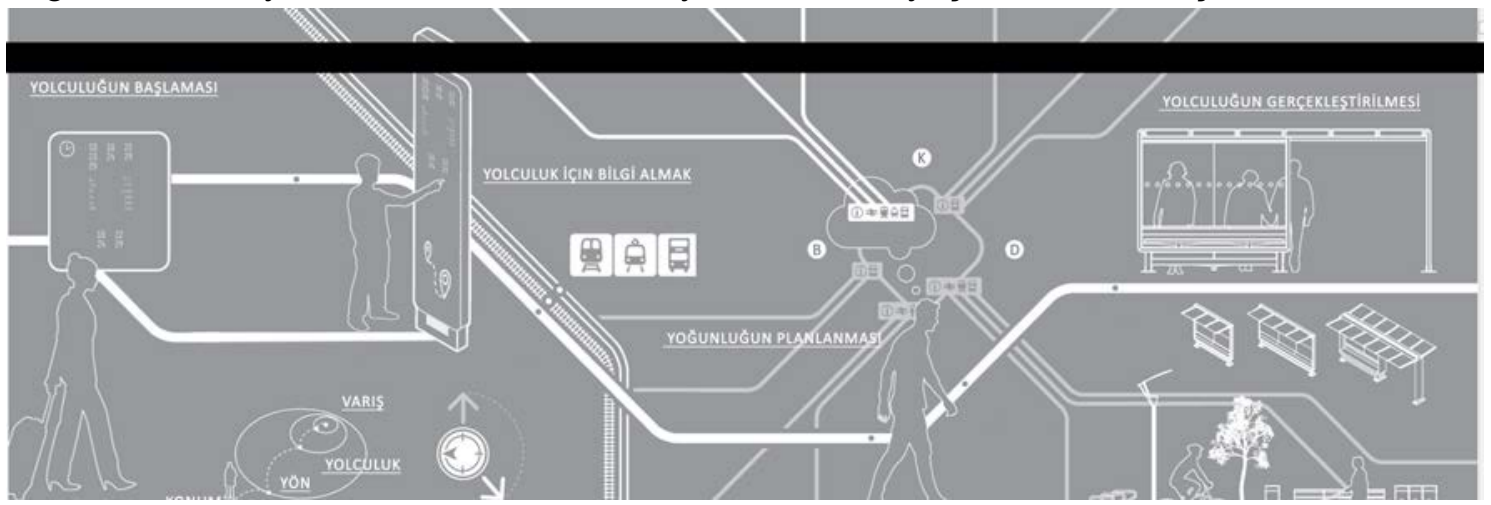

Şekil 5: Bilgilendirme Odakı Kent Mobilyaları (Centro and City ID, 2010)

\section{Park Etmek}

Bisiklet kullanma tercihinin bir yolculuk seçeneği olarak tanımlandığı kentlerde, bu iki tekerlekli araç için park yerleri yaratmak çok önem taşımaktadır. Ulaşım aktarma merkezlerinde bulunan bu mobilyalardaki temel amaç, robotik teknolojiyi kullanan tam otomatik sistem ile yerden tasarruf sağlayan yeraltı bisiklet park oluşturmak olmuştur (URL-2). Eco Cycle olarak adlandırılan bu sistemlerde biniciler hesap açtıktan sonra, sistem tarafından bisikletin kasasına tutturulacak bir çip verilir. Bir bisikletçi, bisikleti girişe doğru hareket ettirdiğinde, sistem bisikleti çip sayesinde tanır, ön tekerleği kavrayıp, park etmeye hazır duruma getirir. Daha sonra bisikletler, sahiplerine verilen kartlar ile kolayca sistem tarafından algılanıp, otomatik ses ile uyardıktan sonra yaklaşık 8 dakika içerisinde sahibi tarafından kolayca alınır.

\section{Geçiş Yapmak}

Mobilyaların oluşumundaki temel amaç, yolcu akışının sorunsuz ve verimli bir şekilde çalışmasının sağlamasıdır. Bu mobilyalar, çok modlu biyometrik tanımlama ve doğrulama süreçlerini kullanıp, yolcu akışına yeni bir yaklaşım getirerek, hızlı ve rahat bir yolcu işlemi yaratıp, bekleme sürelerini azaltmak ve en önemlisi turistlerin yoğun olduğu dönemlerde tüm yolcuların akışını daha hızlı hale getrimek olmuştur. Bu sistem, görevlilerinin tüm Otomatik Sınır Kontrolü'nün bir akıllı telefon aracılığıyla izlemesine, tüm işlemleri ve yolcu işlem durumunu, biyometrik kayıtları, kimlik belgesi güvenlik özelliklerini ve kimlik doğrulama, geçmiş kontrollerin sonuçlarını, Vısa uygulamalarını denetlemelerine olanak tanır (URL-3).

\section{2) Enerji Üretebilen Mobilyalar}

Enerjiye olan ihtiyacın gittikçe artması ve küresel ısınmanın önlemesi için oluşturulan çözüm yolundaki en önemli unsur enerji tasarrufu olmuştur. Tasarruf konusu için başvurulan doğal enerji kaynaklarının pek çoğunun kökenini güneş oluşturmaktadır, bu 
enerjiden şimdiki teknoloji ile rahatlıkla ısıtma ve elektrik elde etmek amaçları doğrultusunda yararlanılmaktadır. Ayrıca güneş enerjisi çevre açısından temiz bir kaynak özelliği taşıdığından fosil yakıtlara alternatif olup daha az maliyet ile elde edilmektedir (Abdurrahmanoğlu, 2014). Kaynağı güneş enerjisi olan güneş paneli tabanlı sistemlerin kullanımı gün geçtikçe artmaktadır. Aktarma merkezlerinde dinlenme ve aydınlatma amaçlı kullanılan bu mobilyalar, enerji tasarrufu yaklaşımı çerçevesinde, akıllı teknolojik mekanizmalar ile güçlendirilmiş sistemlerden oluşup, kendi enerjisini barındırdığı güneş panellerinden alan, güneş enerjisi ile beslenen mekanizmalar şeklinde çalışmaktadırlar. Ulaşım aktarma merkezlerinde kullanılabilecek akıllı kent mobilyalar aydınlatma, dinlenme ve temizleme olmak üzere üç grupta ele alınmaktadır (Şekil 6).

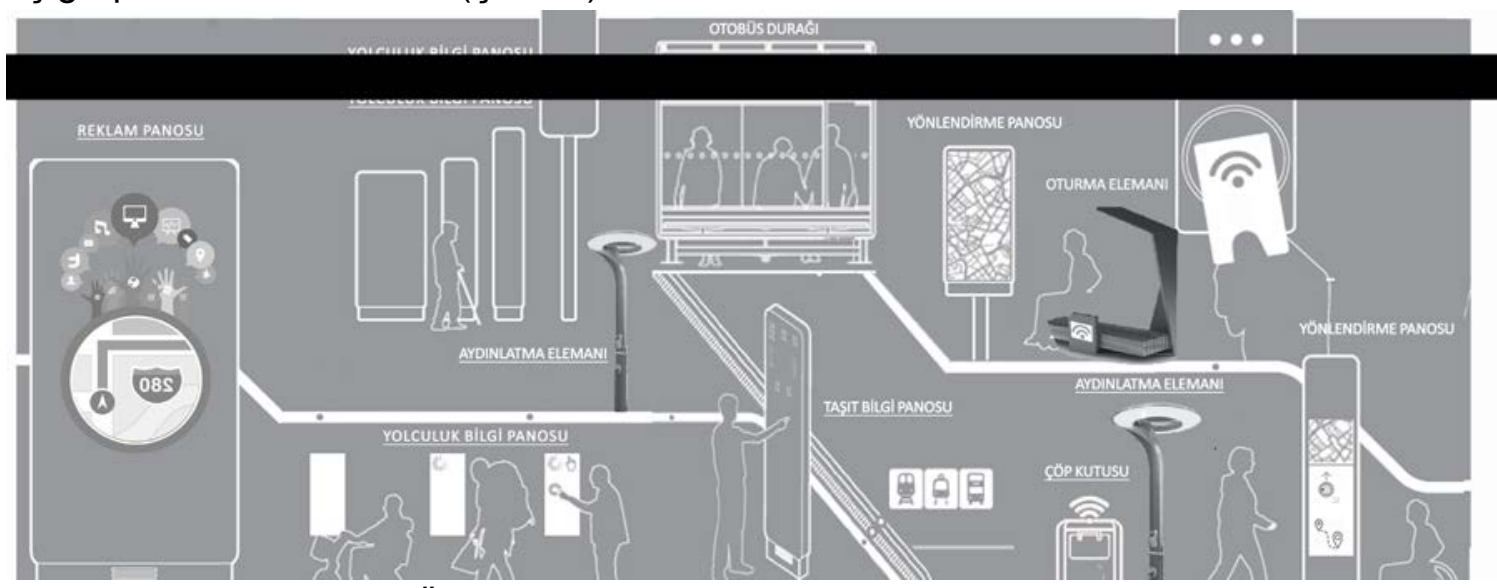

Şekil 6: Enerji Üretebilen Kent Mobilyaları (Centro and City ID, 2010)

\section{Aydınlatma}

Aydınlatma mobilyaları güneş enerjisi ile çalışabilmektedir. Güneş panellerinden gündüz boyunca elde ettikleri enerjiyi aküler vasıtasıyla depolayarak gece boyunca da kullanma olanağı tanımaktadır (URL-4). Bu tür aydınlatma mobilyaları, özel tip ampulleri ile çalışıp, aydınlatmanın yanısıra, güneşten gelen enerji ile bireylerin intiyaçlarına yönelik internet erişimi ve cihazların şarj olanağını sağlayacak sistemler ile donatılmaktadırlar.

\section{Dinlenme}

Günümüzde ulaşım aktarma merkezlerini kullanan bireyler oturma ve dinlenme eylemlerini gerçekleştirdikleri zaman, kullandıkları cihazlar ve erişmek istedikleri bilgilerden dolayı hem dinlenme ve hem internet erişimini sağlayacak mobilyaları tercih etmektedirler. Oturma bankları biçimindeki bu kent mobilyaları güneş enerjisinden beslenerek, mobil ağ sistemi ile donatılmışlardır. Böylece kullanıcıların hem bilgi gereksinimleri ve hem dinlenme intiyaçlarına yanıt verecek şekilde tasarlanmışlardır(URL-5).

\section{Temizleme}

Enerji tasarrufu fikri çerçevesinde, aktarma merkezlerinde kullanılan çöp kutusu mobilyaları, farklı akıllı teknolojik sistemler ile donatılmaktadır. Bu akıllı sistem enerji 
tasarrufu üzerine tasarlanmış, kendi enerjisini barındırdığı güneş panellerinden alıp, yarattığı enerjiyi ile kendini yönetmesinin yanısıra, günümüz şartlarındaki internet bağlantısı vasıtasıyla bilgilendirme işlevlerine de olanak sağlamaktadır (URL-6). Bu olanak, bu tür mobilyalarda yolcuların intiyaç duydukları bilgilerin yanısıra barındırdıkları mekanizma sayesinde mobilya ve görevli kişi (belediye çalışanı) arasında iletişim kurarak, bir çöpün dolu olup alınmasının gerektiğini veya yeterince dolu olmadığının anlaşıımasına olanak tanımaktadır.

\section{DEĞERLENDIRME VE SONUÇ}

Bugünün modern şehir yaşam algısı, hızlı bir şekilde artan mobil ağ bazlı interaktif teknoloji sayesinde, rasyonel fonksiyon görüşünden, deneyimlenebilen sınırsız çeşitliliğe sahip sisteme dönüşmektedir. Bu yaklaşım çerçevesinde, teknolojik ve yenilenebilir enerji kaynaklarına sahip kent mobilyaların tasarım süreci, daha aktif mekânlar yaratmak amaçlı, özgün ve akıllı kavram olgusu içerip bireylerin yaşam tarzı, ihtiyaçları ve davranışları doğrultusunda gelişim göstermektedir.

Düğüm noktaları ve ulaşım türleri arasında entegrasyon sağlayan mekânları oluşturan aktarma merkezlerinde, kent mobilyaların tasarım sürecini oluşturan akılılık ilkeleri, bilgilendirme, yönlendirme, dinlenme ve aydınlatma işlevleri üzerine kurulup, teknolojik bir biçimde, erişebilir ve kullanılabilir özellikleri ile donatılmayı gerektirmektedir. Bu ilkeler kapsamında, bilgilendirme ve yönlendirme işlevlerini sağlayan sistem, mobil ağ sistemi desteğiyle, farklı uygulamalar şekilde bireylerin isteklerini tespit edip bu tespit doğrultusunda kelime anlamından belli olduğu üzere engelli ve normal bireylerin bilgilendirmesini hedeflemektedir. Bu hedefin gerçekleşmesi için yapılan organizasyon kapsamında mobilya ve bireyin akıllı cihazı arasında, mobil ağ sistemi ile bir bağlantı oluşturarak istenilen bilgi cihazın ekranı üzerinde veya mobilyaların kendi tarafından görsel anlatımlar veya sesli mesajlar olarak yayınlanması şeklindedir. Ulaşım aktarma merkezlerinde bu işlevleri kapsayan bilgiler genellikle bireyler için yön bulma, taşıtların varış, hareket ya da kalkış saatleri, trafik yoğunluğu ile ilgili konular, bireyler için en uygun olanak tanıyan alternatif taşıtlar, kent çerçevesindeki önemli veri ve bilgiler, hava durumları ve kısa yolculuk için bilinmesi gereken bilgiler şeklinde olmaktadırlar.

Ulaşım aktarma merkezlerinde dinlenme ve aydınlatma işlevlerini sağlayan mobilyalar ise, enerji tasarrufu fikri çerçevesinde, akıllı teknolojik sistemler ile donatılmış sistemlerden oluşup, kendi enerjisini barındırdığı güneş panellerinden alan, güneş enerjisi ile beslenen mekanizmalar şeklinde çalışmaktadırlar. Bu mobilyalarda üretilen enerji mobilyanın kendi tükettiği intiyacın yanısıra bireylerin ihtiyaçlarının bir kısmını da karşılamaktadır. Böylelikle güneş gibi doğal kaynaktan alınan enerji bireylerin cihazlarını şarj etme kapasitesine sahip bir nitelik taşımaktadır.

Sonuç olarak, anlatılan konular çerçevesinde ulaşım aktarma merkezleri kapsamındaki kent mobilyalarında kurgulanmış olan akıllı sistemler bireylerin talepleri ve potansiyelleri ile bütünleşik olup bugünün mekânsal kullanım ihtiyaçları gözetilerek geliştirilmektedir. Bu süreç içeresinde kent mobilyaları işlevsel oldukları kadar görsel açıdan da önem taşımaktadırlar. Ulaşım aktarma merkezlerindeki bu gelişmelerin en 
temel amacı; teknolojik bağlamdaki intiyaçlara yönelik oluşan bilgi ağırlıklı gereksinimlere, çağa ayak uydurabilen sistemler ile donatılmış mekanizmalar aracılığıyla çevreci çözümler oluşturmaktır.

\section{KAYNAKLAR}

Abaszadegan, Mohammad, Rezazade, Raziye, Mohamadi, Maryam, Transit Oriented Development and Role of Tehran Subway System, Bagh-I-Nazar, 8(17, pp. 43-58), Tahran 2011.

Abu Dhabi Urban Planning Council, Abu Dhabi Urban Street Design Manual, United Arab Emirates 2013.

Abdurrahmanoğlu, Ayten, Kent Mobilyaları Tasarımında Sürdürülebilirlik Açısından Enerji Kaynakları, Haliç Üniversitesi, Fen Bilimleri, Endüstri Ürünleri Tasarım Porogramı, İstanbul 2014.

Aksu, Volkan, Özge, Kent Mobilyaları Tasarımında Özgün Yaklaşımlar, İnönü Üniversitesi Sanat ve Tasarım Dergisi, Cilt/Vol. 2 Sayı/No. 6, Malatya 2010.

Akyol, Elif, Kent Mobilyaları Tasarım ve Kullanım Süreci, İstanbul Teknik Üniversitesi, Fen Bilimleri, Şehir ve Bölge Planlama Anabilim Dalı, Peyzaj Mimarılığı Programı, İstanbul 2006.

Albayrak, Güneş, Ece, Aktarma Merkezlerinde Mekânsal Davranışlar: Üsküdar Aktarma Merkezi Örneği, Yıldız Teknik Üniversitesi Mimarlık Fakültesi, Şehir ve Bölge Planlama Bölümü, Megaron Cilt Vol. 11 - Sayi No. 4, İstanbul 2016.

Bayazıt, Nigan, Çağdaş Bir Yaşam İçin Kent Mobilyaları, İstanbul Teknik Üniversitesi, Mimarlık Fakültesi, Endüstri Ürünleri Tasarımı Bölümü, İstanbul 2011.

Centro and City ID, Creating The Canvas For Public Life In Bath, Public Realm And Movement Strategy For Bath City Center, London 2010.

Centro and City ID, Interconnect: ImprovingThe Journey Experience, Transforming Public Transport, ISBN 978-0-9928115-0-1, Bristol 2014

Doğan, Cem, Çağdaş Kent Mobilyası Üzerine Bir İnceleme Örnekler ve Değerlendirmeler, Dört Aylık Mimarlık Kültürü Dergisi • Yıl: 15 • Sayı: 54, İstanbul 2015.

Durmuş, Çağatay, (2008), İstanbul Kent Mobilyaları Üzerine Bir Araştırma, Yıldız Teknik Üniversitesi, Fen Bilimleri, Mimarlık Anabilim Dalı Mimari Tasarım Programı, İstanbul 2008.

JCDecaux, Intelligent Street Furniture, Award-winning Innovative concepts, Paris 2012. 
Krouwel, Peter, Street Furniture, Streetlife Collection 2016-2017, Malmö, Sweden 2017.

Moreton Bay Regional Council, In the Street place, Urban design charter, A Framework for Quality Streetscapes in Moreton Bay Region Redcliffe Parade 2011.

National Association of City Transportation Officials, Transit Street Design Guide, National Association of City Transportation Officials, ISBN: 9781610917490, New York 2012.

Sancak, Ahu, Kentsel Mekan Kimliğinin Oluşumunda Kent Mobilyası Tasarım Kriterlerinin İrdelenmesi, Mimar Sinan Güzel Sanatlar Üniversitesi, Fen Bilimleri Enstitüsü İç Mimarlık Bölümü, Anasanat Dalı, İstanbul 2009.

San Francisco Redevelopment Agency, Transit Center District Plan, Draft for Public Review San Francisco, San Francisco (2009).

Saraçoğlu, Belkıs, Toplu Taşıma Sistemlerinin Entegrasyonunda Aktarma Merkezleri: İstanbul Tarihi Kıyı Bölgeleri Örneği, Bahçeşehir Üniversitesi, Fen Bilimleri Enstitüsü, Kentsel Sistemler ve Ulaştırma Yönetimi, İstanbul 2012.

URL-1. http://www.smithsonianmag.com /(Erişim Tarihi: 11 Kasım 2017)

URL-2. www.giken.com/en/solutions/underground_developments/eco_cycle/ (Erişim Tarihi: 28

Aralık 2017)

URL-3. http://www.vision-box.com /(Erişim Tarihi: 11 Aralık 2017)

URL-4. http://www.nytimes.com /(Erişim Tarihi: 27 Mart 2018)

URL-5. http://www. Strawberry Smart Bench.com/(Erişim Tarihi: 27 Mart 2018)

URL-6. https://www.smartbin.com /(Erişim Tarihi: 27 Mart 2018) 